This item was submitted to Loughborough's Research Repository by the author.

Items in Figshare are protected by copyright, with all rights reserved, unless otherwise indicated.

\title{
Equipment design in inclusive physical activity and disability sport
}

PLEASE CITE THE PUBLISHED VERSION

http://www.ashgate.com/isbn/9780566088599

PUBLISHER

(c) Gower

VERSION

AM (Accepted Manuscript)

LICENCE

CC BY-NC-ND 4.0

REPOSITORY RECORD

Torrens, George E., and Ken Black. 2019. "Equipment Design in Inclusive Physical Activity and Disability Sport". figshare. https://hdl.handle.net/2134/9025. 
This item was submitted to Loughborough's Institutional Repository (https://dspace.lboro.ac.uk/) by the author and is made available under the following Creative Commons Licence conditions.

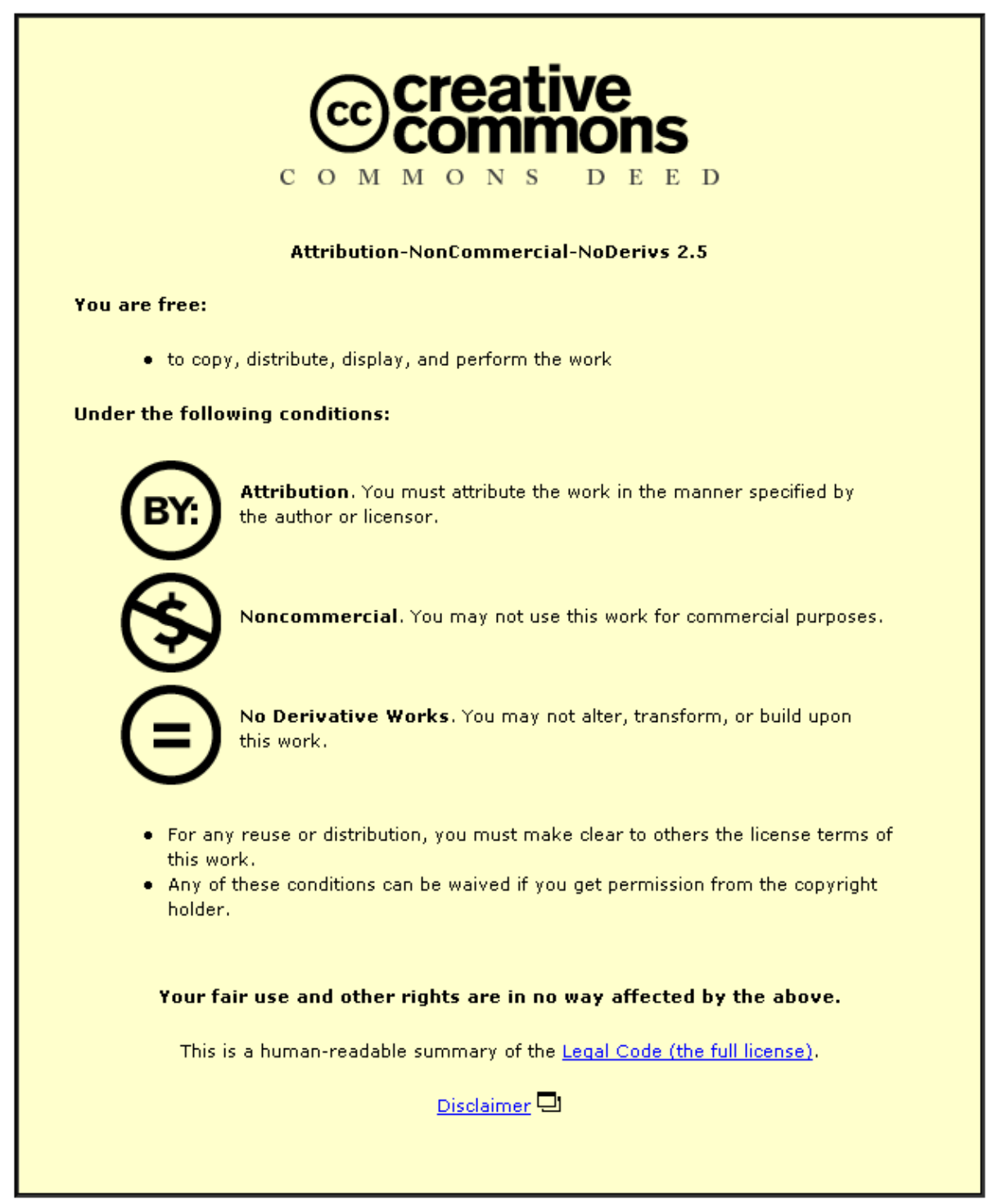

For the full text of this licence, please go to: http://creativecommons.org/licenses/by-nc-nd/2.5/ 
Chapter 5 Equipment design in inclusive physical activity \& disability sport

George Torrens

Lecturer,

Department of Design \& Technology, Loughborough University

\& Ken Black

Independent adviser,

Inclusive physical activity \& sport 


\section{Introduction}

This chapter consists of two parts: an introduction to issues in inclusive design in the context of disability sport; and, the process of inclusive design using a specific disability sport example. This chapter links to a short case study about inclusive design in the context of a national inclusive activity programme (the Inclusive Fitness Initiative).

\section{Part 1: Equipment design and disability sport}

Design issues affecting the participation of disabled people in physical activity and sport are thrown into sharp focus by globally-recognised events like the Paralympics.

In May 2008, Oscar Pistorius (Republic of South Africa), double-amputee track athlete, won an appeal to the Court of Arbitration for Sport enabling him to compete in 'able-bodied' athletics, despite his use of high-tech prosthetic running blades.

Gareth Davies, journalist with the Daily Telegraph commenting on the case in his blog on the Parasport website (www.parasport.org.uk) said:

“.. Pistorius, through pursuing his own dreams, will put the hopes and aspirations of millions of people with perceived disabilities around the world on the map." (Davies $19^{\text {th }}$ May 2008)

'Disability sport', in the sense of competitive opportunities in sport for disabled people, is a relatively modern concept. Although sport for deaf people has its origins in the 1920s, organised competitive sports programmes, like the Special Olympics (1968) and the Paralympics (1988) have a short history (Legg, Emes, Stewart \& Steadward 2004).

The growth of adapted mobility and recreational equipment also has a relatively short-lived history. The lightweight folding wheelchair was first manufactured in the United States in 1933 (by Herbert Everest, an engineer who became a paraplegic following a cave-in, and his friend Harry Jennings, also an engineer), and in the UK its equivalent, the Dingwall Collapsible Wheelchair, became available to some disabled people through the Ministry of Health in the 1950s (Woods \& Watson, 2004). However, specially designed sports chairs were not widely manufactured until much later. ${ }^{1}$

\footnotetext{
${ }^{1}$ Woods and Watson also mention an early wooden folding wheelchair developed in the UK by Carters as early as 1902. 
Standard or generic chairs, such as the infamous $8 \mathrm{BL}$, were not met with universal acclaim by users or therapists, although they were distributed through NHS fitting consultants well into the 1990s. There were some indication, for example, that they contributed to poor posture and resulting back pain and discomfort (Harms 1990). Ease of production and basic functionality dictated mass availability.

Much of the early development of sports and recreational equipment for disabled people was not as a result of commercial enterprise and innovation, but had its origins in rehabilitation following conflict ${ }^{2}$.

Joan Scruton was assistant and secretary to Sir Ludwig Guttmann, neurosurgeon at the Stoke Mandeville spinal injuries unit (near Aylesbury, England), who introduced recreational and competitive sports activities to the rehabilitation programme of his patients, the vast majority of whom were war-injured ex-servicemen. She recalled in 'Paralympics: Where Heroes Come' (Steadward and Petersen 1997) how patients and staff developed the game of wheelchair polo. It was the patients themselves who pushed the boundaries of what was considered possible, creating equipment adaptations that would enable them to achieve their aims.

"They got in wheelchairs, and they had shortened sticks, and a disk for the puck, and they went up and down an empty ward hitting this puck. It was played against the physiotherapists, and later against the local football clubs." ${ }^{3}$

But the perceived increase in public awareness of higher profile disability sport events has influenced the availability of specialist equipment. Nick Webborn, in a July 2004 article on 'Sport and Disability' in the Student BMJ , said:

"As disability sport has evolved, so has the technology. Specialist chairs are available for sports such as tennis, rugby, and basketball. Although sport specific chairs are not necessary for initial participation it does become a consideration as people develop their interest and feel more limited by their equipment." (Webborn ADJ, student BMJ , J uly 2004)

\footnotetext{
${ }^{2}$ A good description of the early history of wheelchair sport, particularly the American experience, can be found in Wheelchair Champions: a history of wheelchair sports by Harriet May Savitz (Universal Publishers, 2006)

${ }^{3}$ Guttmann's ideal was preceded somewhat by the Fürst Donnersmarck Foundation (www.fdst.de) conceived in 1916 by its founder Guido Graf Henckel Fürst von Donnersmarck as a vehicle for the rehabilitation of German war-injured servicemen. Physical activity was core to its philosophy, although for various reasons his vision was not realised until the 1950s.
} 
Frustrated by limited choice and the lack of commercially available wheelchairs, disabled users and athletes began to develop their own manufacturing companies utilising the lightweight materials becoming readily available from other sources, such as cycle frame manufacturers and the aircraft industry. RGK, formed in 1989 by Russell Simms and Greg Eden, both wheelchair basketball players, is one example. Base in the west Midlands of England, RGK extended its operation to the United States in 2002.

Manufacturers, whose own experiences provided a unique understanding of the needs of fellow users, have greatly enhanced the interaction between provider and end user.

The influence of rule changes was a main driver in sports equipment development. Initially, sports wheelchairs, for example, were merely adaptations of standard versions. But gradually, athletes and coaches began to push the envelope. Wheelchair sports rules attempted to limit, whilst users attempted to exploit, possibilities.

A famous example was that of Bo Lindguist, a wheelchair racer who challenged design conventions laid down in race rules in the late 1980s. Athletes were beginning to experiment with the now familiar three wheeled racing chairs, but the rules stated that all chairs must have four wheels. Lindguist entered the Gasparilla race series with a three wheeled chair developed by the US based company Top End, which had a small stabiliser-type wheel attached. There was no denying the chair had four wheels and race directors and officials soon had to admit that the rules could not stand in the way of this major change in race chair design.

In tandem with the extension of human rights legislation, and an increase in awareness of the range of physical activity opportunities available, a large commercial industry has emerged to feed demand. Equipment adapted to the needs and requests of disabled people now cover virtually every known sporting and recreational pursuit, from abseiling and aquatics to sand yachting and skiing (snow and water!).

Huge sums of Government funding are now invested in Paralympic sport. UK Sport is the body responsible for managing and distributing public investment in Great Britain's international sports programmes (www.uksport.gov.uk). The National Audit Office (NAO) reported in 2005 that between 2001 and 2005, UK Sport awarded f83.5 million under its 
World Class Performance programmes to Britain's Summer Olympic and Paralympic sports.

In performance terms, this meant that each medal won at the Athens Paralympics cost $f 0.2$ million of investment! (NAO 2005).

Athletes interviewed by the NAO reported vast improvements in the equipment available to them, as well as services and training, as a result of this funding.

The Australian Government (through its sports arm the Australian Sports Commission) provided \$AUD22.8 million ( $€ 10.3$ million) to Paralympic sport leading towards London 2012 (www.ausport.gov.au/media).

And governments around the world have begun to see the Paralympics as not only as providing opportunities in sport for their disabled people but also as a political platform (perhaps a cynical view). Countries emerging from conflict have used disability sport to help reintegrate war-injured children and adults. Examples of this can be seen in the emergence of Angola, Cambodia, the Islamic Republic of Iran and Iraq as Paralympic nations.

These countries, sometimes with the support of Western aid programmes, have guided former combatants into sport. Western experts have also been recruited to help support the process.

But access to advanced sports and mobility equipment is another matter.

In his book 'The Cultural Politics of the Paralympic Movement' David Howe pointed out that there is a technological inequality that has a negative effect on the ability of disabled athletes in developing and emerging economies to access the equipment they need in order to compete on a par with athletes from wealthier nations.

Howe says: "Those who have the most sophisticated aids are traditionally from the West, and they are the athletes who have the greatest chance of winning medals and breaking records. As a result, the Paralympics risk becoming a show of radical technology rather than a show of athleticism, leaving behind those from the developing world without performanceenhancing technology at their disposal" (Howe, 2008).

Nonetheless, design innovations, including lightweight wheelchairs, and developments in prosthetics, have elements of their origins in sport. In 
turn, these ideas find their way into the design of mobility and other aids for daily living.

\section{Part 2: The inclusive design process}

The brief history above may suggest that the evolution of design for disability sport has been somewhat ad hoc and random, with users influencing change through pressure on competition rules whilst manufacturers responded to the main change by taking advantage of a burgeoning support industry.

The authors will use this section to examine a design process that places the needs of the users and their support network at its centre and asks the question:

"Can the design process in disability sport be made more inclusive?"

Awareness of issues and challenges around inclusion can act as positive drivers in the development of a disability sports product. The adoption of an inclusive approach to the design process, with emphasis on securing input from end users, can move equipment providers towards a closer relationship with the client group.

The design, development and manufacture of a pace clock for partially sighted and blind swimmers will be used later to illustrate the way in which generic aspects of research and development, including the use of resources, materials and manufacturing processes, can be re-focused to integrate the needs of a specific population.

An inclusive design process adheres to the principles of universal design. Universal design is the design of products and environments to be usable by all people, to the greatest extent possible, without the need for adaptation or specialised design ${ }^{4}$.

Jon Christophersen, in the book, 'Universal design, 17 Ways of Thinking and Teaching, provides a seven point definition of universal design. This is summarised in Table 1 with some examples specific to disabled users.

\footnotetext{
${ }^{4}$ See 'Principles of Universal Design - Version 2.0', Center for Universal Design, NCSU, 1997). 
These universal design principles not only apply to assistive technology products ${ }^{5}$ but are desirable aspirations in any design project, demonstrating convenience and ease of use. By their nature, sports products are specialist and considered by manufacturers to be a 'niche' market.

Although the number of disabled people participating in sport, proportional to the general population, is lower than in non-disabled people (as reported, for example, in the Sport England Active People surveys of 2005- 6 and 2007-8 $)^{6}$ the increase in profile of the Paralympics and a perceived 'professionalisation' of disability sports programmes has encouraged many disabled people to get involved in organised sports programmes. This in turn has encouraged some manufacturers to consider investing in the development of a product for a target market.

\footnotetext{
${ }^{5}$ Assistive technology products help a person with an impairment to do activities of everyday living (ADL). Examples include a: wheelchair, reading glasses, crutches, and hearing aid.

${ }^{6}$ www.sportengland.org/index/get_resources/research/active_people. htm - insert survey figures here 


\begin{tabular}{|c|c|}
\hline Definition & Example implication for disabled users \\
\hline 1. Equitable use & $\begin{array}{l}\text { ensuring that the design is equally useable } \\
\text { by a disabled or non-disabled person }\end{array}$ \\
\hline 2. Flexibility in use & $\begin{array}{l}\text { useable by a left- or right-handed person - } \\
\text { particularly applicable to a disabled user who } \\
\text { may have function in one side of the body }\end{array}$ \\
\hline 3. Simple and intuitive use & $\begin{array}{l}\text { reducing complexity and emphasising } \\
\text { simplicity of use, which may be important } \\
\text { when considering users who have cognitive, } \\
\text { language or movement literacy impairments }\end{array}$ \\
\hline 4. Perceptible information & $\begin{array}{l}\text { providing simple operating instructions in a } \\
\text { variety of accessible formats }\end{array}$ \\
\hline 5. Tolerance for error & $\begin{array}{l}\text { reducing or removing hazardous materials, } \\
\text { which may assist use by people whose risk- } \\
\text { awareness may be inhibited }\end{array}$ \\
\hline 6. Low physical effort & $\begin{array}{l}\text { enabling use by people who have low } \\
\text { exercise tolerance without strain or fatigue }\end{array}$ \\
\hline $\begin{array}{l}\text { 7. Size and space for } \\
\text { approach and use }\end{array}$ & $\begin{array}{l}\text { ensuring that the design does not } \\
\text { disadvantage use from a standing or seated } \\
\text { position }\end{array}$ \\
\hline
\end{tabular}

Table 5.1 - Christophersen's 7 point definition of Universal Design (see also the Case Study on the Inclusive Fitness Initiative)

However, there are perceived barriers for a business to invest in a disability sports product. Young and Sandhu (1990) highlighted some of the issues raised by businesses when considering developing assistive technology products. These included:

- a disparate and fragmented market.

- low level investment attracted into a perceived 'niche market'
- higher litigation risk.

- multiple stakeholders involved in purchasing .

These concerns are more apparent when all sports products inherently help their user to push themselves to the limits of their abilities, with the 8 
associated risk of injury. This compounds the perception of the market having a higher risk of litigation.

The issue of multiple purchasing stakeholders is demonstrated in Figure 1. Coaches, club secretaries, sport federations, sponsors, family, friends, healthcare and education professionals can all have an influence on the decision to purchase a product. Each will perceive a different emphasis for the product, from the need for portability and handling by carers, who support the athlete, to cost and storage considered by club secretaries. All must be suitably satisfied before the sports product will be purchased.

Decisions made about the product design specification (PDS) should be based on information or evidence collected. It is important that the emphasis of the product specification and subsequent design is based on the athlete or sportsperson. This is known as evidence-based and usercentred design. Ergonomics and human factors provide appropriate strategies and methods by which these principles may be implemented, integrated with good design practice. 


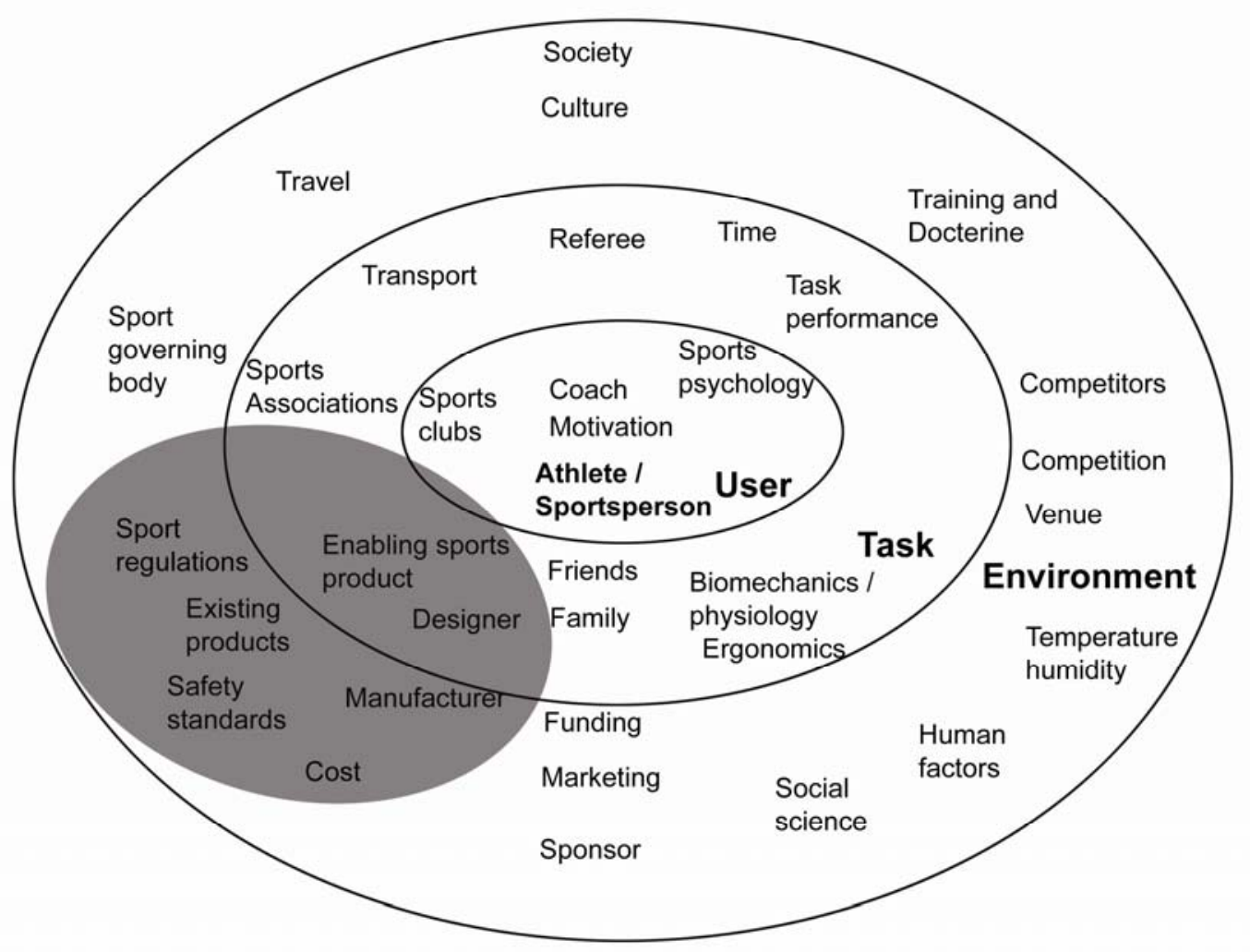

Figure 5.1 Mind map of user, task, environment (UTE) and associated stakeholders. The shaded area indicates the focus for a new sports product design.

The following are examples of what may be considered good practice when researching and developing a new disability sport product. The process outlined is based on a well used format of new product development. There are four main stages to such a process:

\section{Insight}

Defining the needs and aspirations of a target market user or group;

2. Proposition

Producing a product design specification that embodies those needs and aspirations;

3. Synthesis

Producing an optimum design solution that satisfies the product design specification; and,

\section{Realisation}

Manufacturing and validating an optimum design solution ready for use. 


\section{Stage 1: Insight}

Information about the numbers of sportspeople who might use a new product and their needs and aspirations for it are critical to its success. A simple way of considering the aspects that define a new product is to describe the user, task and environment (sometimes referred to as UTE). Table 2 below shows some of the aspects, how they are categorised and how information in each category may be collected.

\begin{tabular}{|c|c|c|c|}
\hline & User & Task & Environment \\
\hline Focus of study & $\begin{array}{ll}\text { - } & \text { gender } \\
\text { - } & \text { age } \\
\text { - } & \text { scale (size) } \\
\text { - } & \text { chysical and } \\
\text { (hanitive ability } \\
\text { coordination, } \\
\text { speed, agility) } \\
\text { - socio-economic } \\
\text { status (how } \\
\text { much money } \\
\text { they have, their } \\
\text { lifestyle) } \\
\text { past } \\
\text { experiences } \\
\text { (personality } \\
\text { and } \\
\text { competitive } \\
\text { experience) }\end{array}$ & 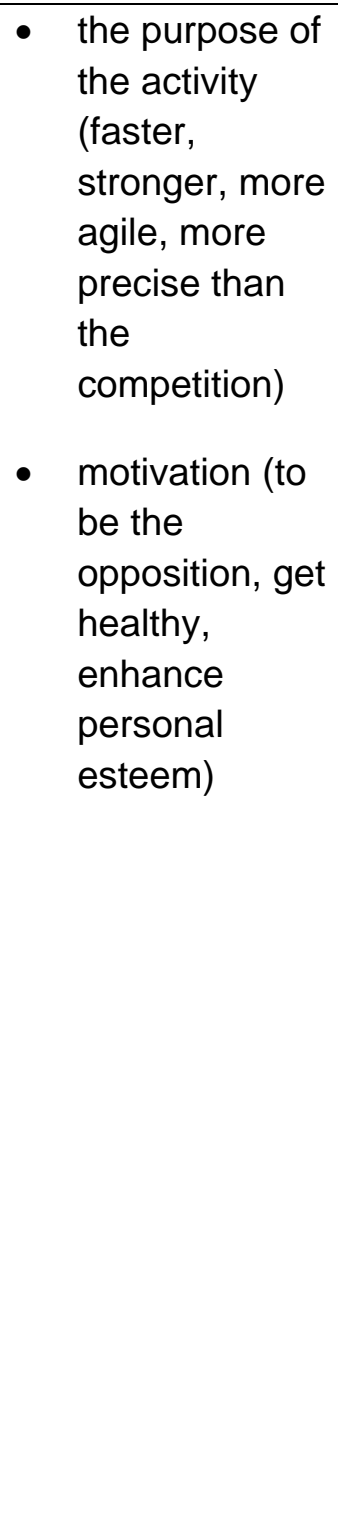 & 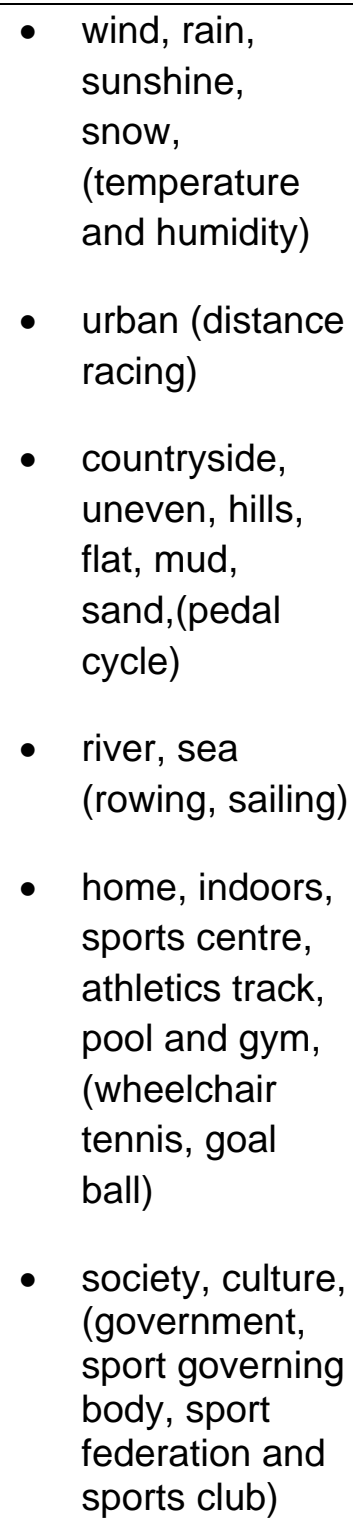 \\
\hline
\end{tabular}




\begin{tabular}{|c|c|c|c|}
\hline $\begin{array}{c}\text { Measurement } \\
\text { tool }\end{array}$ & 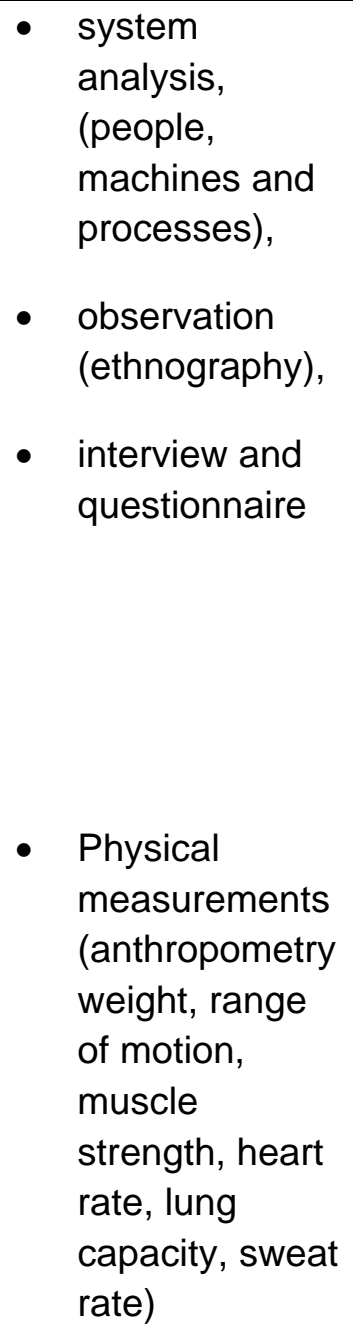 & $\begin{array}{l}\text { observation, } \\
\text { (video analysis, } \\
\text { note taking, } \\
\text { graphic } \\
\text { annotation) } \\
\text { task analysis, } \\
\text { (video analysis, } \\
\text { note taking, } \\
\text { graphic } \\
\text { annotation, } \\
\text { speed, } \\
\text { accuracy, } \\
\text { strength, body } \\
\text { movement, } \\
\text { motion capture, } \\
\text { goniometry, } \\
\text { force sensors) } \\
\text { system, } \\
\text { measurement, } \\
\text { (video analysis, } \\
\text { note taking, } \\
\text { graphic } \\
\text { annotation) } \\
\text { Interview, } \\
\text { questionnaire }\end{array}$ & $\begin{array}{l}\text { - } \begin{array}{l}\text { system } \\
\text { analysis, } \\
\text { (people, } \\
\text { machines and } \\
\text { processes) }\end{array} \\
\text { observation } \\
\text { (ethnography) } \\
\text { interview, } \\
\text { questionnaire, } \\
\text { measurement, } \\
\text { (wind speed, } \\
\text { hydrometer) }\end{array}$ \\
\hline Outcome & $\begin{array}{ll}\text { - } & \text { images } \\
\text { - } & \text { sketches } \\
\text { - } & \text { annotations } \\
\text { - } & \text { comment } \\
\text { - descriptions } \\
\text { - } \text { physical } \\
\text { measurements } \\
\text { and statistics }\end{array}$ & $\begin{array}{l}\text { - } \text { images } \\
\text { - } \text { sketches } \\
\text { - } \text { annotations } \\
\text { - descriptions } \\
\text { - } \text { physical } \\
\text { measurements } \\
\text { and statistics }\end{array}$ & $\begin{array}{l}\text { - } \text { images } \\
\text { - } \text { sketches } \\
\text { - } \text { annotations } \\
\text { - } \text { comment } \\
\text { - physical } \\
\text { measurements } \\
\text { and statistics }\end{array}$ \\
\hline
\end{tabular}

Table 5.2 shows the structure of a UTE and some of the associated data collection methods and equipment. 
How useful the information is to a designer is dependent on how quickly the circumstances for the athlete, coach and other stakeholders change. Issues that can change quickly include:

- Rules of the sport

In disability sport, equipment-related rule changes abound in some disciplines - for example, the maximum allowable height of chairs in wheelchair basketball, so manufacturers of sports chairs will need to take this into account.

- The coaching philosophy and doctrines Coaches may wish to encourage athletes to 'push the boundaries' of what is possible within the constraints of their sport discipline. For example, athletes in certain categories of field event compete using a throwing frame and may demand that the design conforms to the rules while at the same time enabling the athlete the greatest range of movement possible.

- The training routines

Prosthetic limbs can enhance performance. However, amputees may suffer stump soreness that restricts the amount of time that they can run or jump. Designs that provide comfort during prolonged use may be preferred for training over less user-friendly competition equipment.

- The athlete's stage in their training (their ability level, fitness, strength)

An example of this is winter or summer sports clothing (or clothing designed for competition environments different to the training environment). Athletes who have high spinal cord lesions (eg thoracic or low cervical) have difficulties in dissipating heat through sweat, so clothing with inbuilt cooling systems, ice vests and other temperature modifying apparel may be required in hot or humid environments.

Initially, only a small number of individuals need be chosen to provide an insight into needs and aspirations. Small groups can provide most of the issues within a new product area. These requirements and desires can be formalised into a table of questions and validated through interview or questionnaire with a larger group of the target market at a later stage. Collecting information in this way keeps costs in time and money to a minimum. Selection of individuals at the extremes of the target population, e.g. size, gender, age and ability ensures that everyone else in between should 'fit' the product design.

Once areas of concern and need have been identified, the task performance may be assessed and results evaluated. These methods will 
help to identify where there are problems with technique and performance that could be enhanced with an appropriate product design. Beyond the assessment of the sports task to be achieved, a system of use can be defined that includes preparation for use; transport; and, maintenance.

The information collected may be quite complex in the interrelationship between various factors and will require many value-based decisions to be made. The information given by the stakeholders often highlights a number of factors that are important to have embodied in the design. A web or radar diagram can be a good way of identifying the priorities within a design specification (see Figure 2 ). The shape of the resulting diagram can be compared with other existing products and any concept designs that may be produced.

The web or radar diagram helps the designer and stakeholders to prioritise the complexity of attributes, such as performance, portability and appearance. The web diagram design tool can be used to compare opinions and values of different stakeholders' about the same product (as shown in the audible pace clock case study). It can also be used to apply comparable standards across a number of similar existing products (this is known as benchmarking).

The use of this design tool is explained in more detail in the following example of a swimmer's audio pace clock. 


\begin{tabular}{|l|l|l|ll}
\hline Factors/ & Athlete 1 & Coach & Carer & Athlete 2 \\
\hline Performance & 6 & 6 & 1 & 6 \\
\hline Usability & 6 & 6 & 6 & 4 \\
\hline Portability & 1 & 2 & 6 &
\end{tabular}

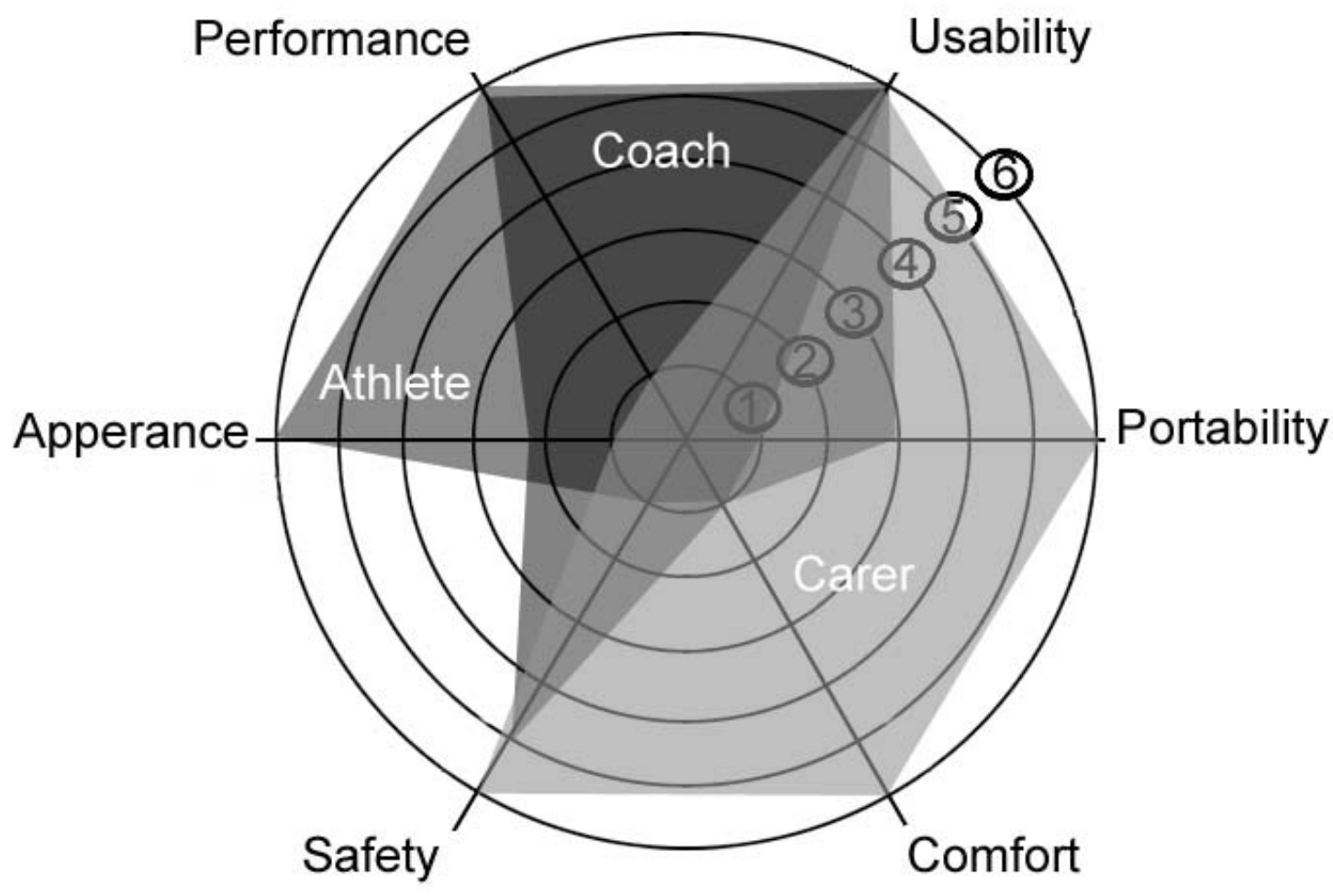

Figure 5.2 Shows a Web diagram that can help when comparing values between products and product design specifications 


\section{Insight: Pace Clock for British Swimming example}

In the case of the pace clock for partially sighted and blind swimmers, the national governing body British Swimming sponsored the research, development and production of the product for their membership. The target number of users was initially estimated at 25 swimmers. These were members of the British Paralympic swimming team. The department of design and technology was tasked with the investigation of need, production of a concept design solution and production of 25 units of the product developed.

The user, task and environment were defined through a series of interviews and observation. These were defined within the first two weeks of the project. Experts within British Swimming were used to advise and guide the development of the design. This strategy was used due to the short timescale for the project (approximately six months to delivery); the small budget available (relative to a conventional mainstream new product design project); and, the athletes and coaches being dispersed over the United Kingdom (UK) and not readily accessible. The experts consisted of a former Paralympic swimmer who was also the project sponsor; a coach and physiologist.

The need for a pace clock that could be used by partially sighted or blind swimmers had already been identified by British Swimming. Conventional pace clocks are located high up on the wall at one end of a training pool. Conventionally, a swimmer would glance at the clock as they set off on their training circuits and check their time on the way back. Their routines, set by their coach required them to complete a return length in a prescribed time. The visual only feedback was of no use to vision impaired Paralympic swimmers. Coaches would instead shout the times to the swimmer or the swimmers themselves would estimate the time per lap by counting. Where the coach had multiple swimmers in the water it was difficult to provide effective coaching to all and counting time by the swimmer was not accurate enough. Changing from one routine to another during a training session was difficult to coordinate for the swimmer and coach, especially when multiple swimmers were training in the pool.

Alongside the definition of user, task and environment, a review of existing products and technologies that could have been used within the new product design was undertaken. This parallel activity reduced the 
timescale for concept design development and enabled more informed alternatives to be proposed.

\section{Note on ethics}

When collecting information from people, especially those who might be considered vulnerable, a code of practice should be followed.

Universities, healthcare organisations and others involved in research activities use a code of practice to ensure both the operator (the person collecting the information) and the participant are safeguarded. ${ }^{7}$ The book 'Evaluation of Human Work - A practical ergonomics methodology' (Corlett et al, 2002) is a good starting point for ergonomics references has specific information about ethics and data collection.

As mentioned above, it may be difficult to gain insight into the needs of the elite athletes and sportspeople if they are a small percentage of the total target market, spread across the country often training as individuals. When they do come together, at training events for example, there is very little time during such events to undertake detailed interviews or specific performance assessments.

\section{Stage 2: Proposition}

The proposition provides the first proactive statements on the requirements and aspirations for the product, once the reflective research activity is close to completion. Producing opinions on, and concept solutions for, the configuration of a product or service through a product design specification before the research is complete can sometimes inform the final stages of investigation. Compiling a product design specification early may identify gaps in knowledge or understanding that require further research or direct the final stages.

The interviews; observation of the task; review of available technologies ${ }^{8}$; and, review of the extremes of physical and cognitive abilities of the

\footnotetext{
${ }^{7}$ There are a number of websites that have useful information on this topic. Sport Scotland has a good ethics overview and brochure for all aspects of ethics in sport. (http://www.sportscotland.org.uk/).

${ }^{8}$ Hand-cycling, for example, now included in the Paralympic programme, was originally developed in the 1980s by non-disabled recreational cyclists.
} 
target market provide the basis for the characteristics that must be embodied in the new product design.

A product design specification is a collection of verifiable attributes that the new product must contain (can be tested). Norman et al provide a good example of a formal product design specification in their book 'Design and technology for schools and colleges' (2000). Their model suggests that a product design specification has a title, list of contents, foreword, scope of specification (a description of the user, task, environment relationship), role of the product or system, definitions of unusual terminology, relevant authorities (health and safety), and related documents and references (such as standards). The attributes described in a product design specification include size, shape, weight, power requirement, and description of preferred use, colour, and other performance characteristics.

\section{Proposition: Pace Clock for British Swimming example}

The attributes defined for the Pace clock were very general.

The product should provide swimmers with an alternative method by which they can pace their swimming and training schedule without the use of the conventional timing clock. The product had to be easy to use by partially sighted or blind swimmers as it must be set up, maintained and transported with the swimmer.

Additional specifications added by the design team included: it should be non-toxic, have no sharp edges, should not exceed $5 \mathrm{~kg}$ in weight, be used one handed, electrical circuits be sealed from water ingress and the unit must not sink if dropped into the pool. The product had to comply with general product safety regulations. ${ }^{9}$

\footnotetext{
${ }^{9}$ The current version of the directive can be found at the Department for Business, Enterprise \& and Regulatory Reform (BERR):

http://www. berr.gov.uk/whatwedo/consumers/Safety/products/generalregulations/index.html
} 
Once attributes for the new sports enabling product have been defined, the priority, value or weighting given to each can be evaluated using a web or radar diagram. A likert ${ }^{10}$ scale is used to provide a value for each attribute, in this case 1 to 6 , where one would be very poor or very bad to very good. The value is then transferred to the diagram. The shape generated enables intuitive assessment of different opinions and emphasis each stakeholder has of the product; in this example study it is the different opinions and values of an athlete, coach and carer about the audible pace clock.

\section{Stage 3: Synthesis}

Once market research and technology review have been undertaken, and the product design specification defined, an optimum compromise of all of the relevant factors can be attempted. Two methods that have been found to be effective for this market are: standardisation and modularity; and, co-designing.

Standardisation and Modularity

An approach that has been proven to be effective when designing assistive technology products is to emphasise standardisation and modularity ${ }^{11}$ within the design. (Torrens and Marshall, 1998)

Standardisation of interfaces, such as electrical and electronic sockets, mechanical fastenings and locating points offers the opportunity to 'plug and play' for example. Modularity offers a wider range of interfaces and enhances the stakeholder's choice of configuration. Through these methods customisation at affordable cost may be achieved.

\section{Co-designing}

The visualisation of the various options offered that demonstrate the balance of factors, embodied in a physical product design solution, may then put through an iterative cycle of co-designing. Co-design is where concept designs or suggested alternative for services are described to a target user and or stakeholders. These suggested designs and alternatives are then redefined during the course of the interview with the target user. Although not used extensively in larger businesses, for this

\footnotetext{
${ }^{10}$ A Likert scale is a linear value scaling tool used in psychology to measure self efficacy

${ }^{11}$ Modularity is the use of components or attributes with standardised interfaces, such as quick change wheelchair rims and wheels or body harness strap clips 
small market size co-designing ensures a quick refinement of any design propositions.

\section{Synthesis: Pace Clock for British Swimming example}

For the Pace clock, a number of options were explored. Technologies already existed for blue tooth and other wireless connections between the swimmer, wearing ear plugs and a communication hub. However, none of the systems produced were suitable or of low enough cost to be viable for this size of market. Technologies used with blind and partially sighted people by the Royal Institution for Blind People in the United Kingdom (RNIB, UK) were also reviewed. Other assistive technology design groups and resources reviewed included the TRACE centre in the United States of America and the Rehabilitation Engineering and Assistive Technology Society of North America (RESNA) and Bath Institute for Medical Engineering (BIME) in the UK. Based upon a number of meetings with the guiding authorities, attention was then turned to the development of concepts around a loudspeaker system that could be used on the side of the pool. Initially, a purpose made electronic timer was proposed. However this was only viable in a large batch quantity of many thousands. The combination of technology cost, limited funding for investment in manufacturing requirement and tooling led to the use of original equipment manufacturer parts in the form of a low-cost music CD player and speakers. The emphasis was placed on developing a water tight container that would enable swimmers and coaches to be able to control the pace clock indicator and routines used whilst in the water or on the poolside.

A number of prototype technology demonstrators were produced to evaluate sound transmission at the poolside and usability of controls. 


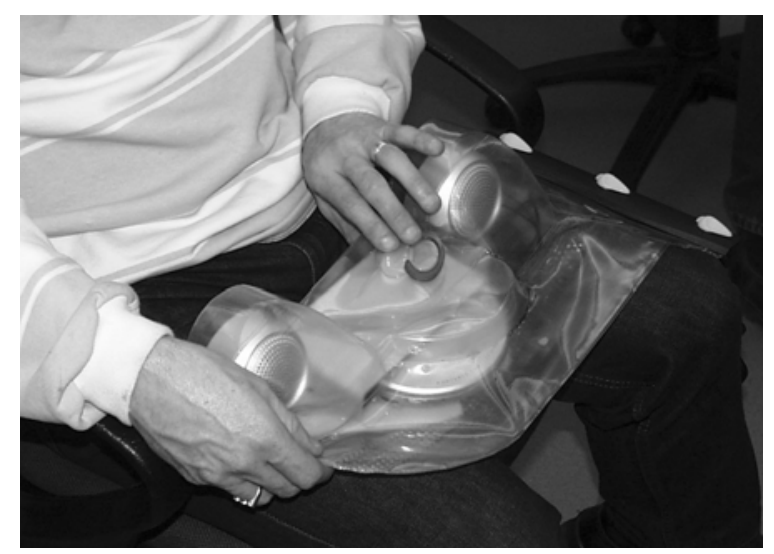

Figure 5.3 shows a blind person (former Paralympic swimmer) during a co-designing consultation session

\section{Stage 4: Realisation}

Following refinement of the product concept design through co-designing, production of a prototype version of the favoured design solution can be done. Realisation of a concept design can overlap with the design development and can help in identifying manufacturing issues early when it may still be possible to revise the design solution. This phase of final development draws primarily on production engineering methodologies. Cost is a critical factor in this phase of the new product development. The final cost is directly dependant on the numbers produced and their unit cost.

Original equipment manufacturer vs In-house

A critical decision to be made is whether to buy-in from an original equipment manufacturer or to manufacture the parts in-house. Many mainstream products are made up for specialist made parts from a single or limited number of world suppliers (e.g. automobile wheel bearings). These parts have many advantages over in-house manufacture. They are made to a high standard, have a 'data' sheet supplied that has specifications and standards to which the component has been made, and have specialist advice about their use from the manufacturer. The disadvantage is that in some cases, the standard components available require in-house made components to connect them together, increasing the cost.

Batch manufacturing methods have been found to be the most appropriate, due to the relatively small numbers in disability sports markets. An economic batch quantity can be calculated once the overhead and set up costs (which are fixed) are added to the unit 
manufacturing costs (which are variable). A break-even point is achieved when the profit per unit made can repay the fixed and variable costs (see Figure 4). The pace clock is a good example of how the more units made, the lower the cost. Many assistive technology products are made in very small batch quantities, with high cost associated with delivery of the product. Delivery costs are not shown in this case study, as the product was distributed by British Swimming. Normally, this doubles the retail cost from the manufacturing coast, shown here. These costs are often unseen by the purchaser. Those involved in raising funds for charitable support groups are not always aware of reasons behind this cost. It is something a designer and manufacturer have to take time to explain to all stakeholders to ensure they know their funds are being appropriately spent.

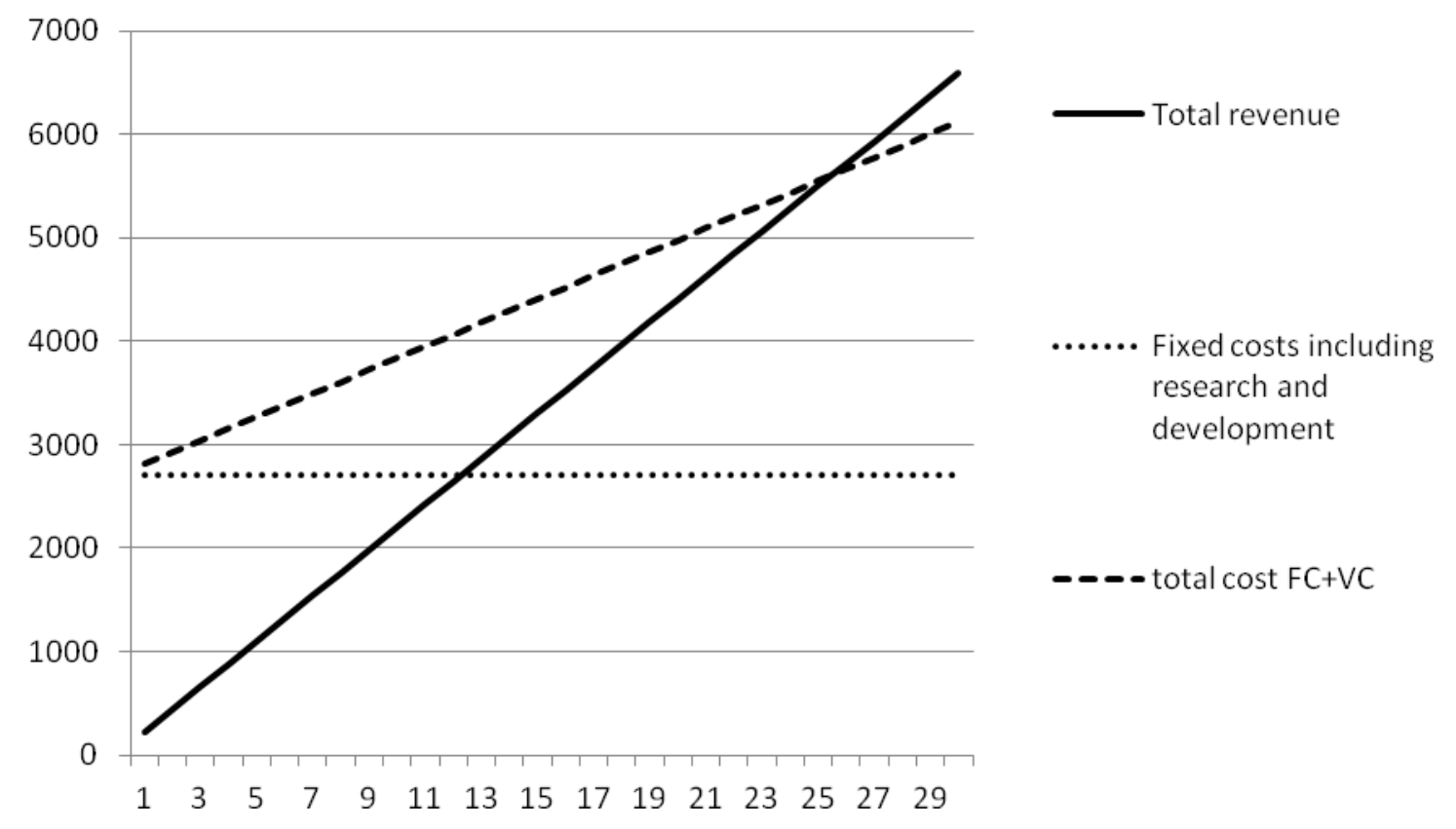

Figure 5.4 shows the breakeven point of the batch at 25 units at $£ 215$ GBP each (manufacturing cost only)

Supporting documentation

Most products require a manual for use to ensure that the user will know how to use their new product effectively. The development of a technical manual is a specialist activity. However, the issues of how to go about producing a good manual and its evaluation is given in the Corlett et al (2002) publication mentioned earlier in the text.

Included in any supporting documentation should be contact details of the manufacturer (even if an individual) and a feedback sheet. The feedback 
sheet enables the supplier to gain feedback on the disability sports product in use. Such information may be used to inform the next cycle of development of the product.

\section{Realisation: Pace Clock for British Swimming example}

A number of methods of manufacture were explored for the pace clock concept designs. Figure 5 shows the vacuum formed outer casing that was semi-flexible was prototyped and compared for tactility with a conventional water tight beach bag. The beach bag (an original equipment manufacture) was favoured because it was a reliable seal up to one metre underwater and had a built in carrying harness. It was found that raised controls could be used within the bag, but conventional portable hi-fi control systems were too small to feel through either container system. A custom made control interface for the CD music player and combined holding chassis made of closed-cell polyethylene foam for the speakers was developed (see Figure 6). The foam was lightweight, inert, non-toxic and had been extensively used in sports equipment products, (often as part of body protection systems).

The custom interface enabled clearly marked controls to be easily identified through the bag material by blind and sighted swimmers and coaches. The controls were of distinctive shape, size and prominence from the surface of the holding chassis. The external control buttons were linked to the smaller control on the music player via a simple sprung loaded pin mechanism. The speakers were presented within the beach bag in such a way that they could be used easily be heard whilst in the water. The top layer of the foam sections was made in yellow. This was to provide a high contrast to the base blue colour for partially sighted users. 


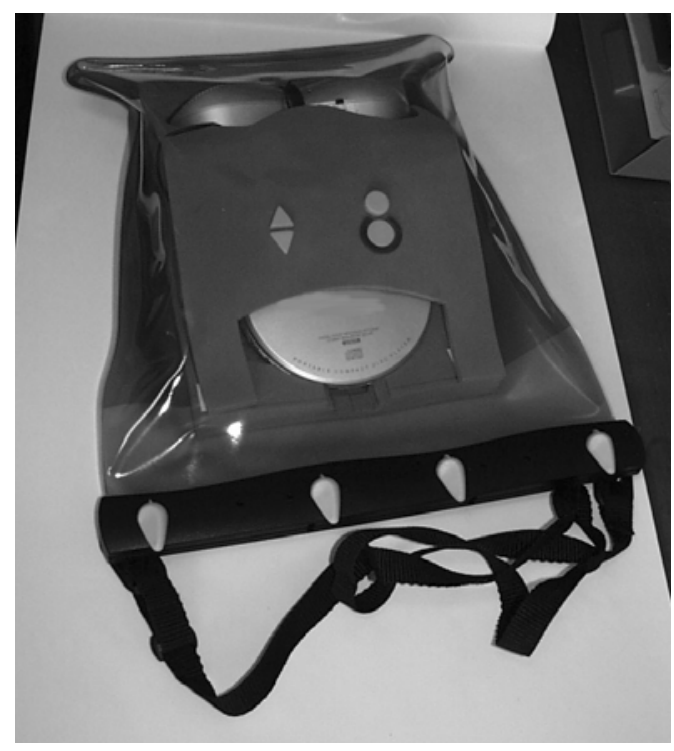

Figure 5.5 shows an early version of the chassis in the original equipment manufacturer (OEM) bag

The issues of maintenance were addressed by ensuring the chassis was asymmetrical with an easily opened front cover to expose the OEM music player inside. Based on feedback of our authorities, it was considered that changing training CDs or batteries would be something all partiallysighted and blind swimmers had experience of doing and did not need additional support.

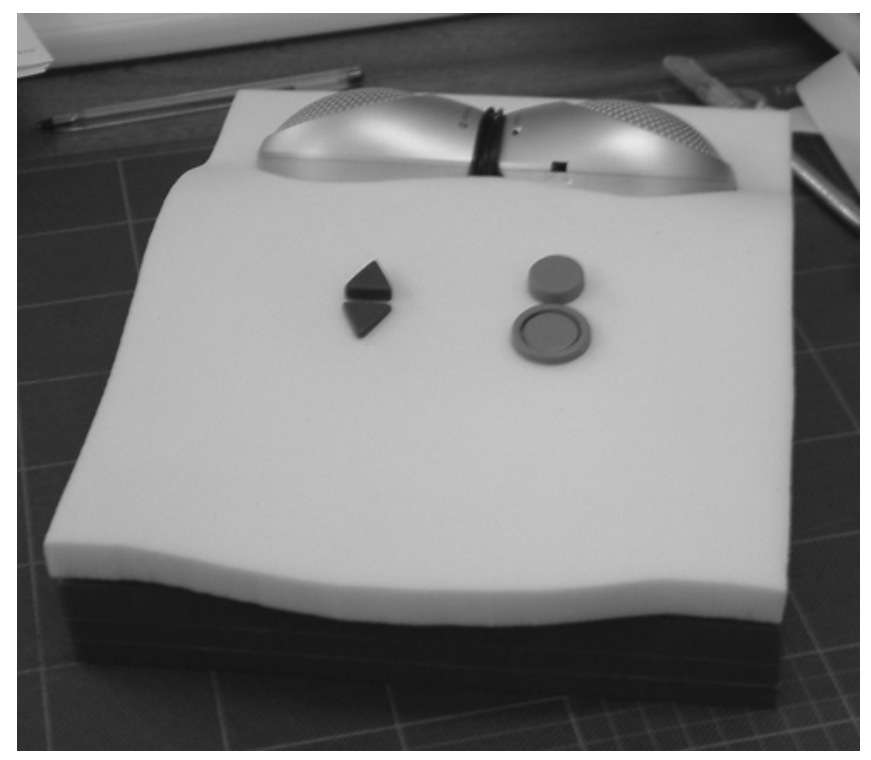

Figure 5.6 shows the closed-cell polyethylene foam chassis with purpose made interface between the OEM CD player and the presentation of OEM speakers for use poolside. 
The usability of the control interface is shown through different shapes and heights of the buttons. The on power button being protected from accidental activation by an external rigid ring.

The supporting documentation was produced in a conventional manual and a Braille version (see Figures 7 and 8 ).

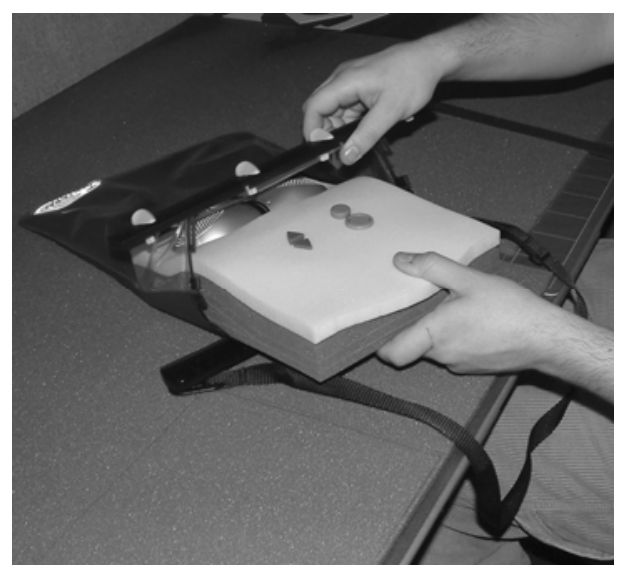

Figure 5.7 shows chassis unit being loaded back into the beach bag

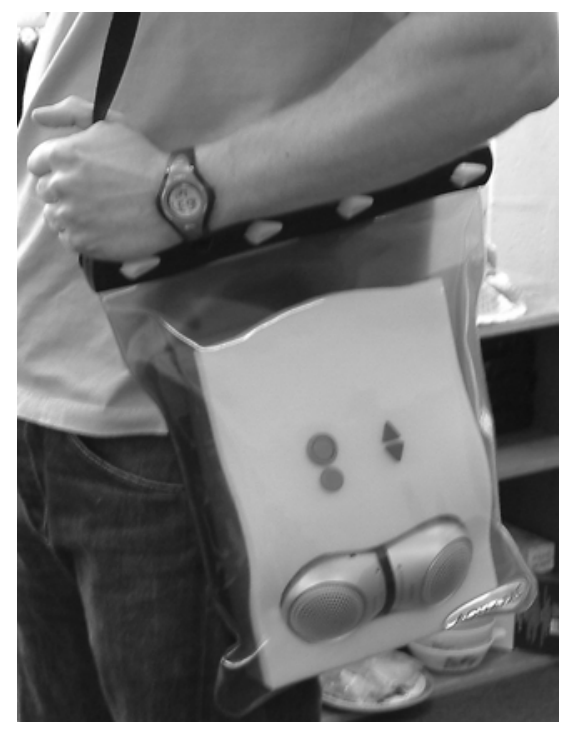

Figure 5.8 shows the bag being carried, but also the position in which it would hang over a starting block poolside

\section{Feedback on use}

Following active use by the consulting experts advising the development, a stiffening strip was added to the back top section of bag of the beach bag. This was to help with easy orientation and insertion of the holding chassis back into the bag. 
Once delivered, the 25 units were distributed to the swimmers and coaches. The most surprising feedback at that time was that the nondisabled swimmers also wanted to use the new pace clock as it meant they didn't need to look up out of the water, which disrupted their practice of the turning technique. Such comments demonstrate that if a product satisfies a need well, there can be other markets that will adopt its use, perhaps in a unique way not previously envisaged. In this case, the modularity, ease of use, appropriate styling and convenience of the pack clock combine to produce an inclusive design.

\section{Key points to consider when designing a disability sports product}

- Check for existing products that may already provide a solution to your needs (it may be from a different application, e.g. protective gloves for rope handling for wheelchair use);

- Check current online research references, blogs and WIKI's for available strategies on your product type and need (insight);

- Contact local resources and experts with your need (e.g. Universities, REMAP ${ }^{12}$, RESNA, Government and Non Government Organisations) these individuals or groups can provide invaluable advice and sometimes real support for manufacture or materials;

- Identify your requirements through observation of the sports person's performance, their comments and document through a PDS (proposition);

- Do some concept designs on paper and take advice from authorities in the field as well as the sportsperson for whom you're designing (synthesis);

- Make simple card or soft prototypes and test (safety first);

- Make more robust prototypes and test (safety first), if in doubt take advice (realisation);

- When considered safe, try the prototype designs with your sportsperson (refine fit and adjust to their specific performance needs);

\footnotetext{
12 Remap is a charity, working through a nationwide network of dedicated volunteers. The volunteers, including mechanical and electrical engineers and carpenters, use their ingenuity and skills to help people with disabilities to achieve much-desired independence in some aspect of their lives, or to enjoy leisure opportunities previously closed to them, by designing tailor-made assistive devices. (www.remap.org.uk) 
- Make a refined prototype, in colours and materials to a higher standard that is more robust for longer term use and provides some enhanced confidence in the product by your user;

- Work out your break-even point for manufacture and ask relevant funding bodies for support; and, finally,

- Get feedback from the user about performance and start again to refine your design!

\section{References}

Davies G., $19^{\text {th }}$ May 2008 - blog in www. parasport.org

Legg D, Emes C, Stewart D \& Steadward R, Historical Overview of the Paralympics, Special Olympics and Deaflympics (in Palaestra, Winter 2004, Vol. 20, No.1)

Woods, Brian \& Watson, Nick, In Pursuit of Standardisation - The British Ministry of Health's Model 8F Wheelchair, 1948-1962 in Technology and Culture 45.3 (2004), 540-568

Steadward R and Petersen C, 1997 - Paralympics: Where Heroes Come Webborn ADJ, Sport \& disability in studentBMJ , July 2004

National Audit Office - UK Sport: Supporting Elite Athletes NAO, $27^{\text {th }}$ J anuary 2005 (HC 182 - SE/2005/9 Session 2004-2005)

P. David Howe, The Cultural Politics of the Paralympic Movement

North Carolina State University: 'Principles of Universal Design - Version 2.0', Center for Universal Design, NCSU, 1997

Christophersen, J., 2002. Universal design. 17 ways of thinking and Teaching, The Norwegian State Housing Bank, Husbanken. 14-15

Sport England - Active People survey 2005-6, www.sportengland.org/index/get_resources/research/active_people.htm

Torrens, G.E., Marshall, R., Burkitt, J. and Kay, G., 1996, Using modularity to produce more competitive assistive technology products, 
Proceedings of the 13th Irish Manufacturing Committee, Limerick. 797804

Young C, Sandhu J. 1995. An examination of the British Assistive Technology SME's and their potential within the single European market, The European context for Assistive Technology, $2^{\text {nd }}$ TIDE Congress, IOS, Oxford. 183-187

Her Majesty's Government Office, 2008. General product safety regulations,

http://www.berr.gov.uk/whatwedo/consumers/Safety/products/generalregulations/index.html: accessed October 2008

Wilson, J.R., Corlett, E.N., eds, 2002, Evaluation of Human Work. A practical ergonomics methodology, second edition, Taylor \& Francis, London.144-168

\section{Resources}

\section{Academic}

TRACE Center, University of Wisconsin-Madison, United States of America, For engineering, assistive technology and disability

\section{( http://trace.wisc.edu/ )}

Design Ergonomics Group, Loughborough University, has extensive knowledge of user-centred design for disabled people and optimising product interfaces

(http://www.lboro.ac.uk/departments/cd/research/groups/erg/)

The Sports Technology Institute, Loughborough University, has extensive expertise in sport product design and disability sports products (http://www. lboro. ac.uk/departments/mm/research/sportsengineering/about.html)

\section{Government}

Independent Living centres of Australia for available products, http://www.ilcaustralia.org/home/assistive_technology.asp

\section{Charitable organisations}


Lighthouse International, a supporting charity group for partially sighted and blind people. ( http://www.lighthouse.org/ )

REMAP GB, a charity supporting local volunteer groups (known as panels) to produce custom made one-off pieces where no suitable product is available. The panels are multidisciplinary and often linked to Universities. (http://www.remap.org.uk/)

\section{Associations}

Australian Rehabilitation and Assistive technologies association, for all aspects of AT product and equipment assessment, design and development.

RESNA, Rehabilitation Engineering and Assistive Technology Society of North America, for all aspects of assistive technology product and equipment assessment, design and development (www.resna.org).

The International Platform on Sport and Development is a resource on best practice in sport, supported by a number of charitable and commercial organisations. (http://www.sportanddev.org/)

Disability Sports is a resource for all interested in sporting activities related to those with a disability. (http://www. disabilitysports.co.uk/)

Bath Institute for Medical Engineering (BIME) for research and development within assistive technology products (http://www.bath.ac.uk/bime/)

\section{Non Government Organisations}

Disabled Living Foundation, for information about all aspects of assistive technology products (http://www.dlf.org.uk/)

The Research Institute for Consumer Affairs, RICAbility, an independent consumer research charity focusing on the needs of elderly and disabled people, (http://www. ricability.org.uk/)

The Foundation for Assistive Technology (FAST) supports innovation in product development and good practice in service provision in the UK. (http://www. fastuk.org/)

\section{Commercial}

Naidex UK is one of the biggest assistive technology product exhibitions, there are equivalents in many countries. (http://www.naidex.co.uk/) 


\section{Other}

Additional resources and design tools relating to real and virtual assessment can be found in the Design Ergonomics Research group, Department of Design and Technology, Loughborough University (http://www. Iboro.ac.uk/departments/cd/research/groups/erg/deg_meth ods tools.htm).

These include, SAMMIECAD (anthropometry manikins and accessibility tools) and HADRIAN (a design tool for assessment of activities of daily living and other disability related resources). 